\title{
XRD Analysis in Gundar River Estuary and Beach Sediments of Mookaiyur Area, Ramanathapuram District, South India
}

\author{
R. Karikalan ${ }^{1}$ \\ Department of Geology, \\ Alagappa University, Karaikudi-630003, \\ Tamilnadu, India.
}

\author{
R. Sathasivam ${ }^{2}$ \\ Department of Geology, \\ Alagappa University, Karaikudi-630003, \\ Tamilnadu, India.
}

\author{
S. Rakkiannan ${ }^{2}$ \\ Department of Geology, \\ Periyar University, Salem-636011, \\ Tamilnadu, India.
}

\begin{abstract}
Quantitative analysis was carried out to determine the major and minor constituent minerals present in sediment samples collected at the coastal region between in Mandapam and Vembar, Gulf of Mannar coast, South India by XRD technique. The grain-size distributions of sediments are studied in the study of grain size in relation to mechanism of sediments deposition. The composition of the coastal sediment is dominated by medium to fine sand. The distribution pattern and textural parameters of sediments vary regionally in the Ramanathapuram coastal sediment distribution. Based on the texture of sediments it can be said that the beach consists of medium to fine sand was domains. Sedimentological studies reveal that depositional patterns in the beach are mostly controlled by fluvial and marine processes. The deposition of medium to fine sands in the extreme in our study area attributed to the discharge Vembar and Gundar Rivers. Further, the representative sediment samples were analyzed by XRD technique to yield more information about the minerals. $X$-ray diffraction methods were non-destructive and can be used in the identification of mineralogical composition. These results confirmed that the applied techniques are relatively quicker and more reliable in mineral analysis. The $\mathrm{X}$-Ray diffraction sediments sample analysis proved that the minerals of calcite, quartz, orthoclase, microcline, biotite, hypersthene, hornblende, albite, anorthite sepiolite, illite, chlorite, halloysite Montmorillonite, halite and heavy mineral garnet, zircon, sillimanite, topaz, cobaltite, kyanite, magnetite, hornblende and ilmenite. The followed by minerals are derived from Recent Alluvium and Southern Granulite Terrain in India.
\end{abstract}

Keywords-Coastal sediments- XRD- Mandapam and VemberTamilnadu.

\section{INTRODUCTION}

Grain size studies provide important clues to the sediment provenance, transport history, and depositional environment. The knowledge of sediment size and textural parameters is one of the better tools to differentiate various depositional environments of recent as well as ancient sediments. The sediment texture has also a close relationship to the topography, wave and current pattern and depositional conditions. Over the past century, X-ray diffraction (XRD) has gradually become one of the most important analytical approaches used in the qualitative and quantitative study of geological samples (Clark and Reynolds, 1936; Nagelschmidt, 1938; Taylor, 1978; Bish, 1994; Srodon, 2002; Chipera and Bish, 2013). Analysis of grain size distribution has been widely used by sedimentologists to classify sedimentary environments and transport dynamics. Frequency distributions of sediment grain size analysis interpret the precipitation of sediment when they re-enter the natural environment (David et al., 1994). Grain size is the one of most significant physical property of sediment and commonly used parameter for understanding the processes involved in transportation and deposition of sediments (Inman, 1952; Folk and Ward, 1957; Friedman, 1961; Karikalan et al., 2001; Karikalan et al 2020 a, b, c, d, e, f).

Grain-size parameters are required and the mean size of medium to very coarse silt has proved to be a useful measure of the speed of the depositing flow (McCave, 2008). Geologist employs the sediment particle size data to study the trends of surface processes related to the dynamic conditions of transportation and deposition. Engineers apply grain size to revise sample permeability and stability under load. In the great majority of cases, this has been for non-cohesive sands and gravels. The objectives of a grain-size analysis are to accurately measure the individual particle sizes to determine their frequency distribution, and to calculate a statistical report that effectively characterizes the samples. The mineralogical studies exhibited quartz, mica, feldspar, sillimanite, hornblende, garnet biotite and microcline are derived from the host rocks of Granitoid gneisses, mg-al granulite's and sandstone. This work concluded they variation of mixed sediments deposited by waves, long shore current, wind and fluvial process. In this study, an attempt has been made to analyses the beach sediment characteristics along XRD analysis Gundar river estuary sediments and Mookaiyur river sediments, Ramanathapuram coast, Tamil Nadu. 


\section{STUDY AREA}

The location of the study area is the latitude between $09^{\circ} 08^{\prime} 00^{\prime \prime} \mathrm{N}$ to $9^{\circ} 10^{\prime} 11^{\prime \prime} \mathrm{N}$ and longitude $78^{\circ} 28^{\prime} 01^{\prime \prime} \mathrm{E}$ to $77^{\circ} 30^{\prime} 01^{\prime \prime} \mathrm{E}$, the Gundar river estuary at Mookaiyur, Gulf of Mannar is situated in the southern part of Tamil Nadu. The gundar river Originated from the Eastern slopes of the Sathuragiri and Andipatti hill ranges above Water flows through Aruppukkottai joint at the Bay of Bengal. The estuary is connected to the sea during the rainy season due to over usage usually landlocked for the rest of the year. Study area map (Fig.1.) Physiographic features represented by both depositional and erosional landform such as estuary, beach ridges, coastal sand dunes, paleo - barrier, paleo - tidal flats, mudflats and abandoned river channels. The Gundar river is the main branch of Vaigai river it is originated from Sathuragiri and Andipatti hill ranges then enters in the district near Anankulam and flows via southeastern direction finally enters the Bay of Bengal in Mookaiyur region.

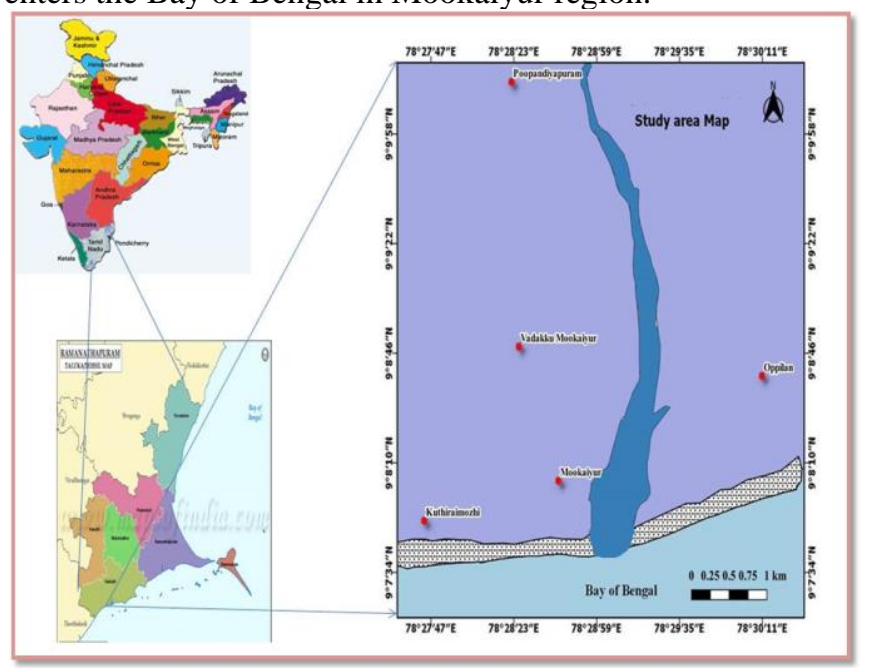

Figure 1. Location map of the study area

\section{MATERIALS AND METHODS}

The selected representative of 7 beach sediment samples from the study area was subjected to X-Ray diffraction analysis through XRD instrument "X PertPro" installed in the laboratory of the department of physics, Alagappa University, Karaikudi. The powdered beach sediment samples were directly analysed for general mineralogical studies by setting $2 \Theta$ position values from 0 $80^{\circ}$ in the XRD instrument. The XRD patterns or X-Ray diffraction of the mineral were identified through respective D spacing values and their intensity and also from other published literatures. The D spacing values, 2 theta values, relative intensity and name of the minerals are given in the table 1-7.

\section{1. $X$ Ray Difraction analysis}

\section{RESULTS}

$\mathrm{X}$-ray powder diffraction (XRD) is a versatile technique that can be used to identify any sediment substances. It can also be used to quantify the proportions of different minerals or indeed many other substances when they are present in a mixture. Over the past century, X-ray diffraction (XRD) has gradually become one of the most important analytical approaches used in the qualitative and quantitative study of geological samples (Srodon, 2002;
Chipera and Bish, 2013). Many important theoretical works have been published for the application of qualitative and quantitative work (Chipera and Bish, 2013 and Perumal Velmayil, 2017). By scanning the sample through a range of $2 \theta$ angles, all possible diffraction directions of the lattice should be attained due to the random orientation of the powdered material. Conversion of the diffraction peaks to dspacing allows identification of the mineral because each mineral has a set of unique d-spacing. Typically, this is achieved by comparison of d-spacing with standard reference patterns. The mineralogy of gundar river estuary and around beach sediments determined through X-ray diffraction analysis. XRD digital scan data were analyzed using Philips X'Pert Semi-quantitative mineral percentages were determined by multiplying unique peak intensities for each mineral in a sample by relative intensity factors as described and the products for all minerals in a sample were then summed to $100 \%$. Intensity factors were estimated for minerals not found in utilizing values for minerals within the same mineral group. The mineralogical studies exhibited quartz, mica, feldspar, sillimanite, hornblende, garnet biotite and microcline are derived from the host rocks of Granitoid gneisses, mg-al granulite's and sandstone. This work concluded they variation of mixed sediments deposited by waves, long shore current, wind and fluvial process.

The powdered beach sediment samples were directly analysed for general mineralogical studies by setting $2 \Theta$ position values from $0-80^{\circ}$ in the XRD instrument. The mineralogy of the collected ten samples of beach sediments (Table 1-7) of the coastal area was determined through $\mathrm{X}$ ray diffraction analysis. Planes of atoms in the crystal structure diffract the $\mathrm{X}$ - rays and a pattern is produced on a paper chart. When a powdered sample is analyzed, diffraction occurs for each angle of incidence that satisfies the Bragg equation-ray diffraction produces a unique series of reflections on the strip chart, which is known as diffractogram. In X-ray diffraction minerals are identified through' $d$ ' spacing values and their respective intensities (Table 1 to 7). The X-ray diffraction patterns of the beach sediment are shown in Fig. 2 to 8.

\subsection{Beach}

\begin{tabular}{|l|l|l|l|}
\hline S.NO & POS. $\left[{ }^{\circ} \mathbf{2 T H}\right]$ & D-SPACING $[\mathbf{A}]$ & MINERALS \\
\hline 1 & 20.6137 & 4.30883 & Riebeckite \\
\hline 2 & 26.3614 & 3.38097 & Quartz \\
\hline 3 & 27.7630 & 3.21338 & Scapolite \\
\hline 4 & 36.2678 & 2.47699 & Enstatite \\
\hline 5 & 40.0163 & 2.25319 & Forsterite \\
\hline 6 & 45.5655 & 1.99086 & Halite \\
\hline 7 & 49.8855 & 1.82811 & Microcline \\
\hline 8 & 59.6876 & 1.54920 & Chamosite \\
\hline 9 & 67.4834 & 1.38795 & Fayalite \\
\hline 10 & 77.4022 & 1.23197 & Augite \\
\hline
\end{tabular}

Table 1. XRD Pattern of Beach-2 Sediment Sample 


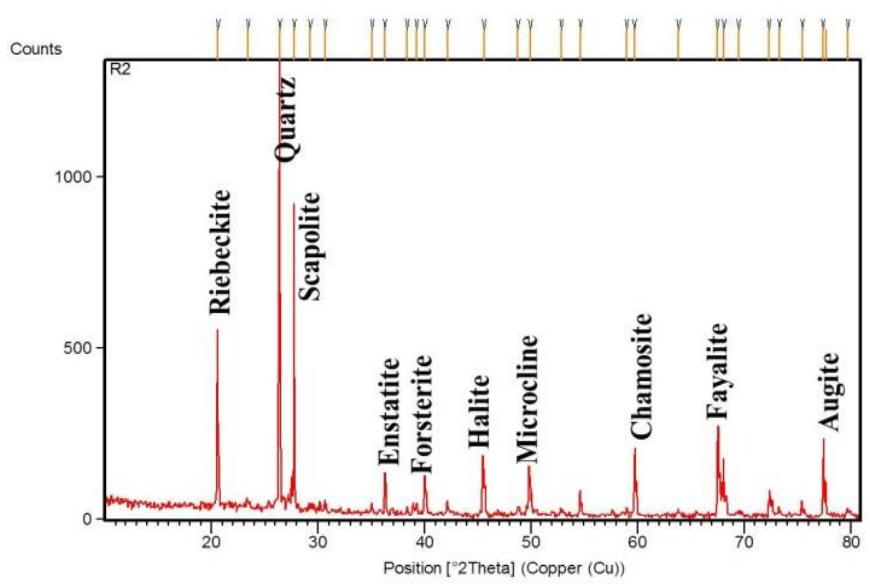

Fig.2. XRD Represents a Beach-2 Sediment Sample

\begin{tabular}{|l|l|l|l|}
\hline S.NO & POS. $\left[{ }^{\circ} \mathbf{2 T H}\right]$ & D-SPACING $[\AA \mathbf{A}]$ & MINERALS \\
\hline 1 & 20.7072 & 4.28960 & Orthoclase \\
\hline 2 & 23.4462 & 3.79432 & Oligoclase \\
\hline 3 & 26.4962 & 3.36407 & Mica \\
\hline 4 & 28.2567 & 3.15835 & Enstatite \\
\hline 5 & 40.1346 & 2.24682 & Stishovite \\
\hline 6 & 42.3268 & 2.13539 & Hematite \\
\hline 7 & 45.6701 & 1.98655 & Illmenite \\
\hline 8 & 50.0205 & 1.82349 & Halite \\
\hline 9 & 59.7759 & 1.54712 & Hypersthene \\
\hline 10 & 68.2022 & 1.37507 & Diopsite \\
\hline
\end{tabular}

Table 2.XRD Minerals of Beach-5 Sediment Sample

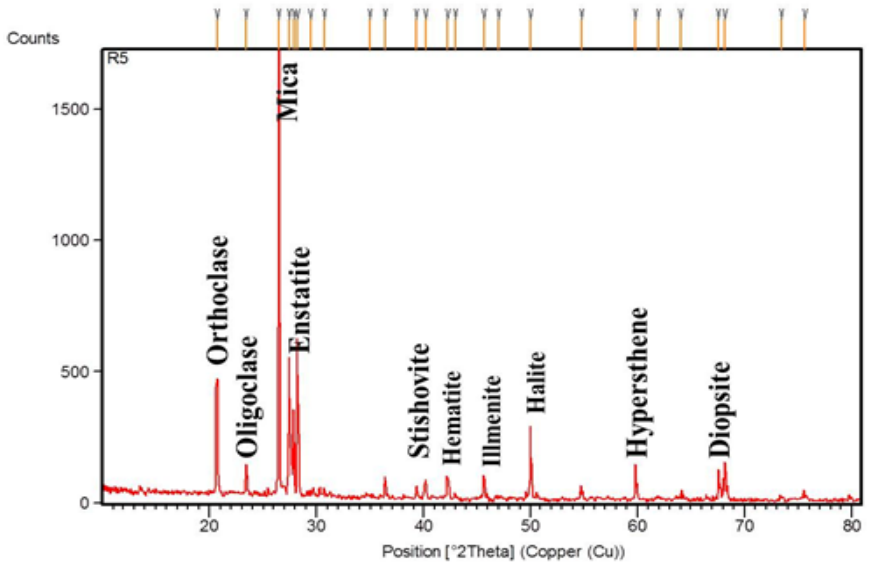

Fig.3. XRD Represents a Beach-5 Sediment Sample

\begin{tabular}{|l|l|l|l|}
\hline S.NO & POS. $\left.^{\circ}{ }^{\circ} \mathbf{2 T H}\right]$ & D-SPACING $[\mathbf{\AA}]$ & MINERALS \\
\hline 1 & 20.5480 & 4.32248 & Stilbite \\
\hline 2 & 23.2827 & 3.82058 & Forsterite \\
\hline 3 & 26.3653 & 3.38048 & Biotite \\
\hline 4 & 27.5191 & 3.24131 & Potash Aluminum \\
\hline 5 & 30.0166 & 2.97706 & Oilgoclase \\
\hline 6 & 39.2030 & 2.29804 & Andalusite \\
\hline 7 & 42.1676 & 2.14308 & Enstatite \\
\hline 8 & 49.8723 & 1.82856 & Illmenite \\
\hline 9 & 59.6618 & 1.54980 & Biotite \\
\hline 10 & 67.4376 & 1.38878 & Kyanite \\
\hline
\end{tabular}

Table 3. XRD Minerals of Beach-10 Sediment Sample

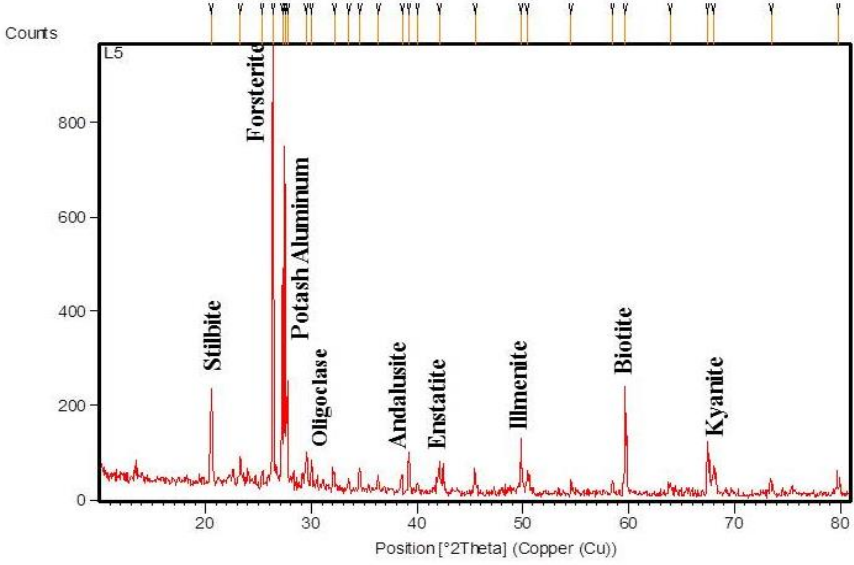

Fig.4. XRD Represents a Beach-10 Sediment Sample

\begin{tabular}{|l|l|l|l|}
\hline S.NO & POS. $\left[{ }^{\circ} \mathbf{2 T H}\right]$ & D-SPACING $[\mathbf{A}]$ & MINERALS \\
\hline 1 & 20.7186 & 4.28726 & Orthoclase \\
\hline 2 & 26.5148 & 3.36175 & Muscovite \\
\hline 3 & 27.8942 & 3.19857 & Oligoclase \\
\hline 4 & 30.2110 & 2.95835 & Plagioclase \\
\hline 5 & 31.5745 & 2.83364 & Cristobalite \\
\hline 6 & 36.4215 & 2.46689 & Monticellite \\
\hline 7 & 42.3378 & 2.13486 & Siderite \\
\hline 8 & 45.6884 & 1.98579 & Ilite \\
\hline 9 & 52.2697 & 1.75020 & Fayalite \\
\hline 10 & 59.8183 & 1.54612 & Kammerrerite \\
\hline 11 & 65.4623 & 1.42582 & Silimanite \\
\hline 12 & 73.3262 & 1.29112 & Kyanite \\
\hline
\end{tabular}

Table 4.XRD Minerals of River Etuary-2 Sediment Sample

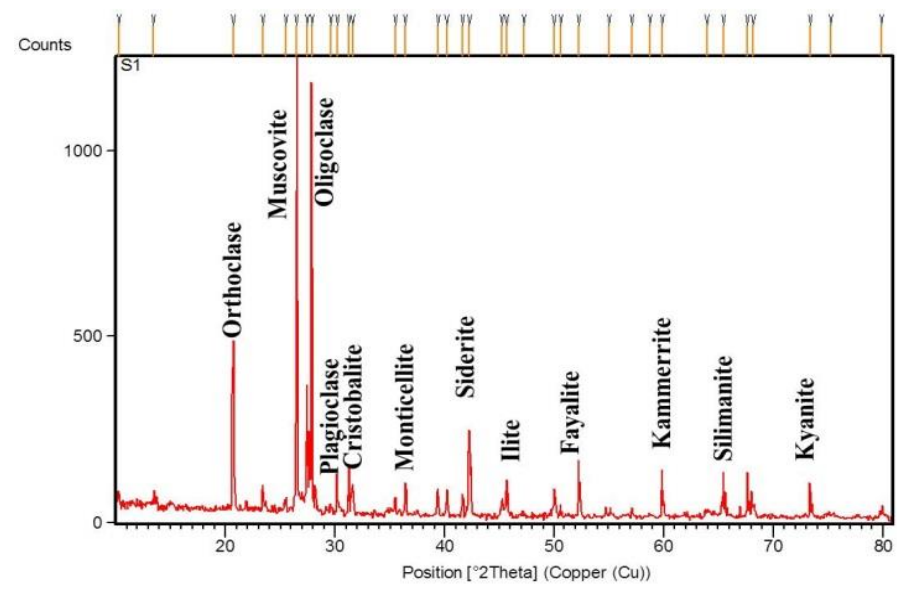

Fig.5. XRD Represents a River Estuary-2 Sediment Sample

\begin{tabular}{|l|l|l|l|}
\hline S.NO & POS. $\left[{ }^{\circ} \mathbf{2 T H}\right]$ & D-SPACING $[\mathbf{\AA}]$ & MINERALS \\
\hline 1 & 20.6144 & 4.30869 & Riebeckite \\
\hline 2 & 23.3423 & 3.81096 & Forsterite \\
\hline 3 & 26.4293 & 3.37243 & Biotite \\
\hline 4 & 27.8131 & 3.20771 & Labradorite \\
\hline 5 & 36.3408 & 2.47219 & Enstatite \\
\hline 6 & 40.1108 & 2.24810 & Olivine \\
\hline 7 & 49.9552 & 1.82572 & Illmenite \\
\hline 8 & 59.7332 & 1.54812 & Lepidomelane \\
\hline 9 & 67.5147 & 1.38738 & kyanite \\
\hline
\end{tabular}

Table 5.XRD Minerals of Beach-7 Sediment Sample 


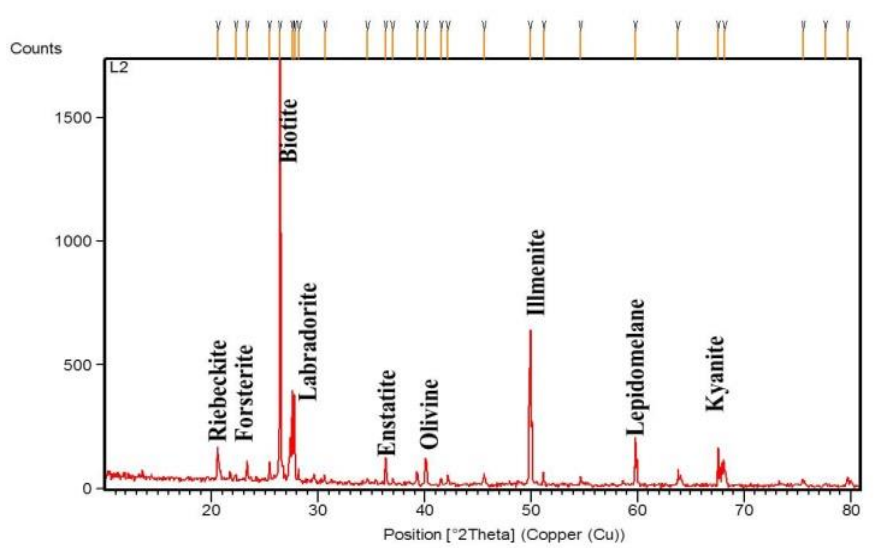

Fig.6. XRD Represents a Beach-7 Sediment Sample

\begin{tabular}{|l|l|l|l|}
\hline S.NO & POS. $\left[{ }^{\circ}\right.$ 2TH.] & D-SPACING [̊] & MINERALS \\
\hline 1 & 20.6827 & 4.29461 & Potash Alumnium \\
\hline 2 & 26.9187 & 3.31222 & actinolite \\
\hline 3 & 27.6041 & 3.23152 & Bytownite \\
\hline 4 & 30.2920 & 2.95062 & Plagioclase \\
\hline 5 & 31.5397 & 2.83668 & hornblende \\
\hline 6 & 39.3035 & 2.29239 & Kaolinite \\
\hline 7 & 42.0620 & 2.14822 & Hussite \\
\hline 8 & 50.0146 & 1.82370 & Yoderite \\
\hline 9 & 57.1786 & 1.61106 & Andradite \\
\hline 10 & 59.8260 & 1.54594 & Lazuarite \\
\hline 11 & 67.5849 & 1.38611 & Monticellite \\
\hline 12 & 75.5077 & 1.25914 & Almandine \\
\hline
\end{tabular}

Table 6. XRD Minerals of River Estuary-5 Sediment Sample

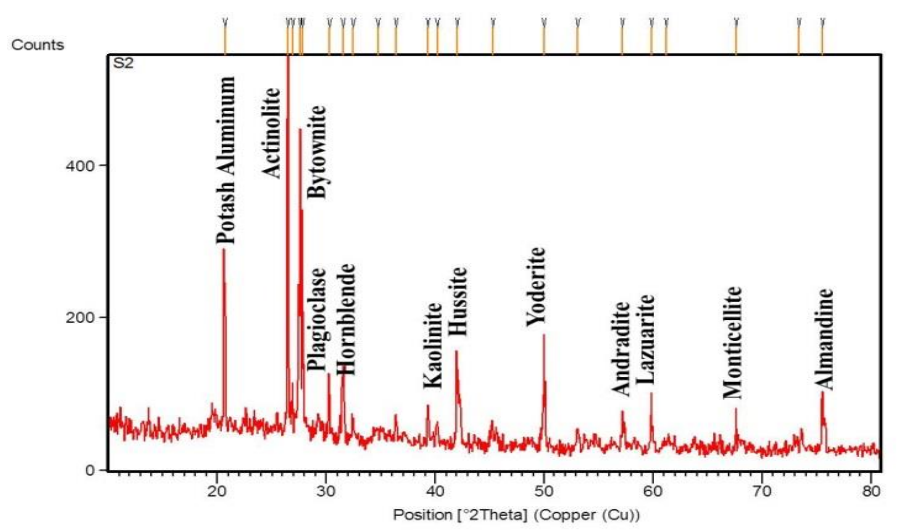

Fig.7. XRD Represents a River Estuary-5 Sediment Sample

\begin{tabular}{|l|l|l|l|}
\hline S.NO & POS. $\left[{ }^{\circ} \mathbf{2}\right.$ TH. $]$ & D-SPACING $[\AA \mathbf{A}]$ & MINERALS \\
\hline 1 & 20.6552 & 4.30028 & Gibbsite \\
\hline 2 & 26.4340 & 3.79641 & Pumpellyite \\
\hline 3 & 23,4331 & 2.83885 & Actinolite \\
\hline 4 & 27.8026 & 3.26503 & Indite \\
\hline 5 & 31.5150 & 3.20890 & Plagioclase \\
\hline 6 & 27.3153 & 3.37184 & Kaolinite \\
\hline 7 & 36.3423 & 2.47209 & Kyanite \\
\hline 8 & 41.5602 & 2.17299 & Phlogophite \\
\hline 9 & 59.7667 & 1.54733 & Biotite \\
\hline 10 & 67.5317 & 1.38708 & Monticellite \\
\hline
\end{tabular}

Table 7.XRD Minerals of River Estuary-10 Sediment Sample

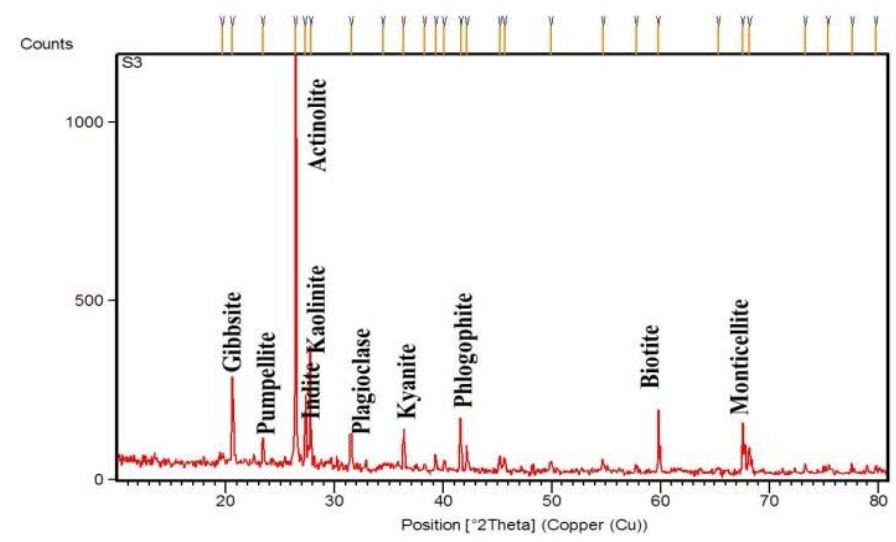

Fig.8. XRD Represents a River Estuary-10 Sediment Sample

\section{DISCUSSION}

The study region is underlain by the recent sediments followed by Cuddalore sandstone formation. It is a chief source of quartz. The gundar river estuary sample XRD mineralogy result show a predominant in quartz, mica, feldspars, Sillimanite, hornblende, Actinolite, Kyanite and Biotite following minerals indicate they source rocks of Granitoid gneisses, mg-al granulite's and Mg-Al Granulite's, and hornblende Biotite gneiss derived from Sathuragiri and Andipatti hill ranges and beach sandstone. Some beach sample mineralogy show a garnet, Illmenite, and magnetite raised beaches with sand bars parallel to the present coastline, light minerals removed by winnowing of waves. The enrichment of heavies in the study area could also be attributed to the selective entrainment due to present day coastal processes. This clearly indicates that in premonsoon period the erosional activities are predominant than the postmonsoon. Sediments were transported from river and estuary towards the beach and marine regions. In pre-monsoon whatever sediment deposited were transported and shifted due to long shore current action. But, in the post-monsoon, due to depositional environment whatever the sediments deposited is mainly due to the multi-source like riverine and marine influence is observed.

\section{CONCLUSSION}

- The mineralogical studies exhibited quartz, mica, feldspar,Sillimanite, hornblende, garnet biotite and microcline are derived from the host rocks of Granitoid gneisses, mg-al granulite's and sandstone.

- This work concluded they variation of mixed sediments deposited by waves, long shore current, wind and fluvial process. This work demonstrates the different origin of sediment deposition.

\section{ACKNOWLEDGEMENT}

This research paper published under the RUSA Phase 2.0 (MHRD), in the head of curriculum development fund, the infrastructure facilities are utilized by the research scholar in the Department of Geology, Alagappa University, Karaikudi. 


\section{REFERENCES}

[1] R.Karikalan, S. Bangaru Priyanga, S. Rakkiannan (2020 a). Textural Analysis of Coastal Sediments in Mandapam area, Gulf of Mannar Coast, Tamilnadu, India. Infokara Research, Volume 9, Issue 3, Page No 780-790: ISSN NO: 1021-9056.

[2] R.Karikalan, S. Bangaru Priyanga, S. Rakkiannan (2020 b). Mineral Identification of Coastal Sediments in between Mandapam and Vembar, Gulf of Mannar Coast, Tamilnadu, India. Infokara Research, Volume 9, Issue 3, Page No 835-841: ISSN NO: 10219056.

[3] R.Karikalan, S. Bangaru Priyanga, S. Rakkiannan (2020 c). Depositional Environments of coastal Sediments from Mandapam and Vembar region, Gulf of Mannar Coast, Tamilnadu, India. Aegaeum Journal, Volume 8, Issue 3, Page No 1225- 1235: ISSN NO: 0776-3808.

[4] R. Karikalan, S. Bangaru Priyanga, S. Rakkiannan (2020 d). X-Ray Diffraction Patterns for Quantitative analysis of coastal sediments in between Mandapam and Vembar, Gulf of Mannar Coast, South India. International Journal of Engineering Research \& Technology (IJERT) Vol. 9 Issue 04, Page No 169-173, ISSN: 2278-0181.

[5] R. Karikalan, R. Sathasivam, S. Rakkiannan (2020 e). Grain size distribution studies in Gundar river estuary and beach sediments of Mookaiyur area, Gulf of Mannar Coast, Ramanathapuram District, Tamil Nadu, India. Aegaeum Journal, Volume 8, Issue 4, Page No. 1120- 1127, ISSN NO: 0776-3808.

[6] R. Karikalan, R. Sathasivam, S. Rakkiannan (2020 f). Spatial grain size distribution of beach and Gundar River Estuary sediments of Mookaiyur, Gulf of Mannar coast, Ramanathapuram District, Tamilnadu, India. Infokara Research, Volume 9, Issue 4, Page No 209-217, ISSN NO: 1021-9056.

[7] Bish, D.L., 1994. Quantitative X-ray diffraction analysis of soils. In: Amonette, J.E., Zelazny, L.W. (Eds.), Quantitative Methods in Soil Mineralogy: Soil Science Society of America. Madisen, pp. 267-295 (Chapter 9).

[8] Chipera, S.J., Bish, D.L., 2013. Fitting full x-ray diffraction patterns for quantitative analysis: a method for readily quantifying crystalline and disordered phases. Adv. Mater. Phys. Chem. 03, 47-53.

[9] Clark, G.L., Reynolds, D.H., 1936. Quantitative analysis of mine Dusts. Ind. Eng. Chem. Anal. Ed 8, 36-40.

[10] Folk R. L., \& Ward M. C., (1957). Brazos River bar (Texas): a study in the significance of grain size parameters. Journal of Sedimentary Petrology, 27 (1), 3-27.

[11] Friedman, G.M, and Sanders, E.J (1961). Distinction between dune, beach and river sands from their textural characteristics. Jour. Sedi. Petrol., 27: 3-26.

[12] Inman D. L., (1952). Measures for describing size of sediments. Journal of Sedimentary Petrology, Vol.19, pp. 125- 145.

[13] Karikalan. R., K. Anbarasu. And G. Victor Rajamanickam, (2001). Coastal Geomorphology of Portnova region, south Arcot district, Tamilnadu. Indian J. Geomorphol., 6(1, 2): 157-169.

[14] Mc Cave, I. N. 2008 Size sorting during transport and deposition of fine sediments: Sortable silt and flow speed. In: Contourites. Developments in Sedimentology, 60 (60). Elsevier, Amsterdam, pp. 121-142.

[15] Nagelschmidt, G., 1938. On the atomic arrangement and variability of the members of montmorillonite group. Mineral. Mag. 25, 140-155.

[16] Perumal Velmayil 2017. Petrography and Geochemistry of Calcrete Deposit in and around Sathankulam Region, Southern Tamilnadu, India manonmaniam Sundaranar University, Tirunelveli, (Http://Hdl.Handle.Net/10603/207324).

[17] Srodo_n, J., 2002. Quantitative mineralogy of sedimentary rocks with emphasis on clays and with applications to K-Ar dating. Mineral. Mag. 66, 677-687. 